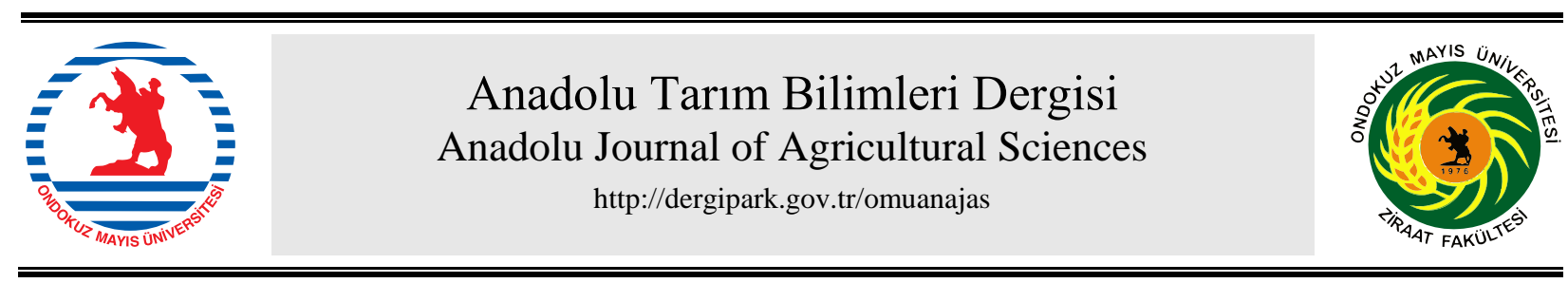

\title{
Araştırma/Research
}

Anadolu Tarım Bilim. Derg./Anadolu J Agr Sci, 34 (2019)

ISSN: 1308-8750 (Print) 1308-8769 (Online) doi: 10.7161/omuanajas.515077

\section{Tüketicilerin bölge orijinli içme sütü tüketim memnuniyetlerine dayalı ürün profillerinin belirlenmesi: Iğdır İli örneği}

\author{
Yavuz Topcu*, Süleyman Yalçın \\ ${ }^{a}$ Atatürk Üniversitesi, Ziraat Fakültesi, Tarım Ekonomisi Bölümü, Erzurum \\ *Sorumlu yazar/corresponding author: yavuztopcu@ atauni.edu.tr
}

Geliş/Received 19/01/2019 Kabul/Accepted 19/08/2019

\begin{abstract}
ÖZET
Çalışmanın amacı, perakende seviyesinde tüketicilerin bölge orijinli içme sütü tüketim memnuniyeti üzerinde etkili olan faktörleri belirlemek ve daha sonra onların toplam faydalarını maksimum kılan ürün profillerini belirlemektir. Araştırmanın verileri, Iğdır ilinde içme sütü tüketen 160 hane halkından tesadüfü olarak toplanmıştır. Elde edilen veriler, tüketicilerin içme sütü tüketim memnuniyeti üzerinde etkili olan faktörlerin nispi önemleri ve faktör seviyelerinin kısmi faydalarını belirlemek ve daha sonra tüketim frekansları ile segmente edilen tüketicilerin toplam faydalarını maksimim ve minimum k1lan ürün profillerini tasarlamak için Konjoint Analizi kullanılmıştır. Araştırma sonuçları, tüketicilerin içme sütü tüketim memnuniyeti üzerinde üretim tekniği (\%30), fiyat (\%16), marka (\%15.3) ve bölge orijini (\%15) faktörlerinin en yüksek nispi öneme sahip olduğunu göstermiştir. Diğer taraftan; organik üretim, pastörize süt, Doğu Karadeniz Bölge orijini, tam yağlı süt, özel marka ve düşük fiyat gibi faktör seviyelerinin kısmi faydaları yüksek bulunmuştur. Bu bulguların ışığında en yüksek toplam faydayı sağlayan 7 numaralı içme sütü profili, Doğu Karadeniz orijini altında özel markalı ve düşük fiyatlı organik tam yağlı pastörize sütler ile dizayn edilmiştir. Perakende seviyesinde, bu faktörler ile faktör seviyelerine göre dizayn edilmiş olan bölge orijinli içme sütü profilleri tüketicilerin toplam faydalarını maksimum kılarak, onların tüketim memnuniyetlerini önemli ölçüde artırabilir
\end{abstract}

Determing product profiles based on consumers' consumption satisfaction towards drinking milk with the region of origin: Case of Igdır province

\begin{abstract}
The aim of the study was to determine the factors effecting on consumers' consumption satisfaction towards drinking milk with the region of origin at the retailer level, and then to determine the product profiles maximizing their total utilities. Research data were collected randomly from 160 households consuming drinking milk in Igdir province. The data were used for Conjoint Analysis to determine the relative importance of the factors and the partial utilities of their levels related to drinking milk consumption satisfaction of the consumers, and to design the product profiles maximizing and minimizing total utility of the consumers segmented by their consumption frequencies. The result of the study highlighted that the production technique (\%30), the price $(\% 16)$, the brand $(\% 15.3)$ and the region of origin $(\% 15)$ factors on the consumers' consumption satisfaction towards drinking milk with the region of origin were of the highest relative importance. On the other hand, the partial utilities of the factor levels such as organic production, pasteurized milk, Eastern Bleak Sea origin, whole-fat milk, private brand and lower price were found much higher. In the light of these findings, number 7 drinking milk profile were designed by organic whole-fat pasteurized milk with private label and lower-priced under Eastern Bleak Sea origin. As a result, the profiles of drinking milk with the region of origin designed by these factors and their levels at the retailer levels could increase the consumers' consumption satisfaction by maximizing their total utilities.
\end{abstract}

Anahtar Sözcükler: Conjoint analiz Ordinal fayda Orthogonal dizayn Tüketim memnuniyeti
Keywords: Conjoint analysis Ordinal utility Orthogonal design Consumption Satisfaction

(C) OMU ANAJAS 2019 


\section{Giriş}

Son yıllarda doğal faktörlerden biyolojik varlıklara uygulanan gen modifikasyonları ve kimyasallarla muamele hem doğal kaynaklar ve canlılar üzerinde deformasyonlara hem de gida ürünlerinin temel fonksiyonları yanında canlıların çeşitli düzeylerde toksinlere maruz kalmasına neden olmaktadır. Bütün bu olumsuzluklardan kaynaklanan kronik sağlik problemleri, insanları satın aldıkları ürünler hakkında daha çok araştırma yapmaya, bilgiye ulaşmaya ve bunlar arasından özenli bir seçim yapmaya zorlamaktadir (Miles ve Frewer, 2001; Chen, 2007; Kan ve ark., 2012; Topcu ve ark., 2015). Dikkate alınan bu seçim kriterleri, tüketicilerin korunan bölge orijini (PDO) ve coğrafik işaretler (PGI), geleneksel özellik garantisi (TSG) gibi orijin tanımlamaları altında çeşitli üretim (organik, doğal ve konvansiyonel) ve işleme tekniklerini (ev tipi, fabrika tipi ve yoğun teknolojik) temel alan taze ve doğal yerel çiftlik ürünleri gibi kavramların ortaya çıkmasına ve bunlara yönelimin yoğun bir şekilde artmasına neden olmuştur (Furnols ve ark., 2011; Lui ve ark, 2013; Schleenbecker ve Hamm, 2013; Barnes ve ark., 2014; Braghieri ve ark., 2014; Marcoz ve ark., 2014; Chamorro ve ark., 2015).

$\mathrm{Bu}$ yönelim içerisinde tüketiciler; daha doğal ve sağlıklı, kimyasallardan arındırılmış ve çevre üzerinde negatif etkisi bulunmayan, doğal kaynakları koruyan ve gelecek nesillere daha iyi bir dünya miras bırakmak için satın alma tutum ve davranışları sergilemektedir. Diğer taraftan üreticiler de tüketicilerin ihtiyaç ve isteklerini dikkate alarak, tüketiciler ile sosyal refah arasında bir denge oluşturabilmek için üretim ve pazarlama stratejilerini güncel tutmak ve bağımlı müşteriler yoluyla işletmenin sürdürülebilirliğini mümkün kılmaya çalışmaktadırlar. Bunun için işletmelerin belirli bir mamul hattında hedef piyasalardaki tüketicilerin satın alma karar modellerini analiz ederek, onların ihtiyaç ve isteklerine cevap verebilen mamullerin konumlandırılması ve yaşam evrelerinin dinamik tutulması büyük önem arz etmektedir. Bu stratejik anlayış içerisinde tüketicilerin bölge orijinli gıda tüketim tercihleri ve satın alma kararları üzerinde etkili olan perakende seviyesindeki dişsal ürün nitelikleri ve pazarlama karması bileşenlerine odaklı mamul profillerinin dizayn edilmesi sadece tüketici ve arz edenlerin toplam faydalarını maksimum kılmaz aynı zamanda bölgesel kalkınmaya da olanak sağlayabilir.

Nitekim araştırma bölgesinin agro-ekolojik yapısı, doğal kaynakların muhafazası ve hayvancılığın yüksek rakımlı ve kirletici kimyasallardan uzak mera alanlarına dayalı olarak sürdürülmesi, hayvansal ürünlere özellikle de çiğ süte mutlak bir üstünlük sağlamaktadır. Bölge için nispi avantaja sahip olan çiğ sütün duyusal kalite niteliklerinin pazarlama karması bileşenleri ile bütünleştirilerek gerçek ya da genişletilmiş süt ve süt ürünleri imajının gerçekleştirilmesi hem tarımsal üretim değerinin artırılması hem de kırsal kalkınmanın temin edilmesinde önemli avantajlar sağlayabilir.
Birleşmiş Milletler Gıda ve Tarım Örgütü tarafından yayınlanan dünya tarımsal üretim değeri raporlarına göre, dünya tarımsal üretim değerinde en yüksek orana sahip olan ürünün, süt ve süt ürünleri olduğu belirtilmiştir (FAOSTAT, 2017). Diğer taraftan süt ve süt ürünleri, Amerika Tarım Birimi (USDA)'nın oluşturduğu besin piramidinde ve USDA'nın Sağlıktan Sorumlu Bölümü (DHHS)'nin oluşturduğu beslenme rehberinde yeterli ve dengeli beslenme için bahsedilen dört besin grubundan biridir. Dolayısıyla bireylerin yeterli ve dengeli beslenmesi için tüketilmesi önerilen süt tüketimi; yaş, cinsiyet ve fizyolojik duruma göre değişiklik göstermesine karşın, her grup için tüketilmesi zorunlu olan bir besin komponentidir (Miller ve ark., 2000).

İnsanoğlunun yaşamının her evresinde gerekli olan süt ve süt ürünleri, makro ve mikro besin elementleri için iyi bir alternatif olmasının yanında bazı önemli mineraller, protein ve vitaminlerin de temel kaynağ durumundadır. Yüksek değerli proteinleri ve tüm esansiyel aminoasitleri içeriği nedeniyle önemli bir kalsiyum, fosfor, magnezyum ve potasyum kaynağı (Murphy ve ark., 2008) durumunda olan süt, özellikle çocukluk ve yaşlılık dönemleri başta olmak üzere yeterli ve dengeli beslenme için gerekli olan bir gıda maddesi ve bileşeni niteliğindedir. Ayrıca vücudun hayati fonksiyonunu sağlayan kalp, sinir ve kas hücreleri için gerekli olmakla beraber kemik erimesini engelleyen, sindirim sistemini düzenleyen, diş çürüklerini önleyen, bazı bağırsak hastalıklarını tedavi eden, beyine enerji veren, mide rahatsızlıklarını giderilmesine yardımcı olan, mikrobik enfeksiyonlara karşı etkili olan muhteviyata da sahiptir. İfade edilen faktörlerin etkisi altında fizyolojik ihtiyaçtan sağlanacak temel fayda güdüsü, tüketicilerin süt tüketim motivasyonlarını güçlendirmektedir (Allen ve Goddard, 2012; Mobley ve ark., 2014; Li ve Drake, 2015; Grunert ve Aachmann, 2016).

Diğer taraftan, çiğ süte uygulanan 1 sıl işlem esnasında zararlı bakteriler ile birlikte faydalı bakterilerin de zarar gördüğü ve raf ömrünün uzatılması yönünde kullanılabilen katkı maddeler ile antibiyotik ve antiseptik maddelerin süt işlenmesi esnasında kalite düzeyini düşürdüğü; aynı zamanda çiğ olarak satın alınan sütün üretim, sağım, işleme, muhafaza ve satış sürecinde çeşitli kirleticilere ve yetiştiricilik aşamasında da mikrobiyolojik açıdan çeşitli kontaminasyonlara maruz kalınmasından kaynaklanan hastalıkların ve risk unsurlarının insanlara bulaşma endişeleri, tüketicilerin satın alma kararları üzerinde negatif motivasyonlara neden olduğu çeşitli araştırmalarla rapor edilmiştir (Hill ve Lynchehaun, 2002; Gündüz ve ark., 2013; Karakaya ve Akbay, 2014; Konar ve ark., 2014; Markham ve ark., 2014; Walke ve ark., 2014).

Sütün hem temel besin nitelikleri hem de işlenmiş/çiğ süt niteliklerine dayalı bu motivasyon varyasyonları, hedef tüketici kitlelerinin tüketim tercihleri ve satın alma kararları üzerinde sürekli bir değişim yaşanmasına neden olmaktadır. Değişim 
olgusunda tüketicilerin deneyimsel algılarına dayalı içme sütü tercihlerinde duyusal kalite nitelikleri ne kadar büyük önem arz ediyorsa, satın alma sürecinde pazarlama karması bileşenleri ve işleme teknikleri de o ölçüde önem arz etmektedir. Dolayısıyla tüketicilerin içme sütü satın alma kararları; demografik, sosyoekonomik, psikolojik ve kişisel faktörlerin etkisi altında ürün ve pazar odaklı pazarlama karmasına bağlı olarak değişen oldukça kompleks bir yapıya sahiptir (Akbay ve Jones, 2005; Topcu, 2015).

Tüketicilerin içme sütü satın alma kararı üzerinde; fiyat, marka, yağ oranı ve ürün bilgisi (Hill ve Lynchehaun, 2002; Liu ve ark., 2013; Cheng ve ark., 2014; Walke ve ark., 2014); güvenlik ve çevre dostu sertifikası ve satış noktası (Cheng ve ark., 2014); hijyen sertifikası ve işleme teknikleri (Uzunoz ve Akcay, 2012); paket materyali ve dizaynı, reklam ve perakendeci uygunluğu (Hill ve Lynchehaun, 2002; Hollywood ve ark., 2013); kalite ve kalite güvencesi, süt kaynağ1 ve işleme teknikleri (Şeker ve ark., 2012; Karakaya ve Akbay, 2014) gibi dışsal ürün niteliklerine büyük bir önem atfedildiği rapor edilmiştir.

Oldukça kompleks satın alma kararını gerekli kılan içme sütünün dünyadaki toplam üretimi 2017 yllında 653 milyon ton düzeyinde olup, süt üretiminde $\mathrm{AB}-28$ (157 milyon ton), ABD (97.7 milyon ton), Hindistan (83.6 milyon ton), Brezilya (33.5 milyon ton), Rusya (30.9 milyon ton), Çin (30.4 milyon ton), Yeni Zellanda (21.4 milyon ton) ve Türkiye (18.8 milyon ton) lider ülkeler konumundadır. Türkiye 18.8 milyon ton süt üretimiyle dünya siralamasında 8. sirada yer alırken, toplam üretilen sütün \%91'i sığırdan temin edilmektedir (ASUD, 2019; FAOSTAT, 2019; WDS, 2017). Yaklașık 7.5 milyar nüfusa sahip olan dünyada, kiși başına ortalama süt ve süt ürünleri tüketim miktarı $111.3 \mathrm{~kg}$ olup, gelişmiş ülkelerde $180-575 \mathrm{~kg}$, gelişmekte olan ülkelerde $75 \mathrm{~kg}$ ve Türkiye'de ise 236 kg'dır. Özelikle Rusya (180 litre), Ukrayna (123 litre), Avustralya (113 litre), Yeni Zellanda (108 litre), ABD (82 litre), Kanada (82 litre), AB-27 (61 litre) kiși başına içme sütü tüketiminde ilk siralarda yer almaktadır (WDS, 2017). Fakat Türkiye ve araştırma bölgesinde kişi başına içme sütü tüketimi 18 ve 5 litre olup, dünyada lider ülkelerle karşılaştırıldığında süt ve süt ürünlerinde 1lımlı fakat içme sütü tüketiminde oldukça düşük tüketime sahibiz.

$\mathrm{Bu}$ mantıksal çerçeve içerisinde araştırma bölgesi olan Iğdır ilinin bölge orijini ve geleneksel spesifik ürün garantisi altında yüksek duyusal kalite niteliklerine sahip ham süt üretimine karşılık, temel fayda güdüsünü karşılamak ve toplam faydalarını maksimum kılmak isteyen tüketicilerin düşük içme sütü tüketim trendlerine neden olan satış noktalarındaki alternatif içme sütü profilleri ve ödeme istekliliklerinin homojen tüketici kitleleri bazında analiz edilmesi ve bu doğrultuda pazarlama stratejilerinin oluşturulması büyük önem arz etmektedir. Fakat araştırma bölgesinde konuyla ilgili herhangi bir çalışmaya rastlanmaması, alınacak kararların etkin olmamasına neden olacaktır. Bu yüzden bu çalışma literatürdeki bu boşluğu doldurarak, karar vericilerin isabetli kararlar vermesine olanak sağlayabilir. Bütün bu gerekçelere bağlı olarak, içme sütünün üretim merkezi konumunda olan Iğdır ilinde ikamet eden tüketicilerin içme sütü satın alma kararları üzerinde etkili olan ve perakende seviyesinde dışsal ürün nitelikleri ile pazarlama karması bileşenlerine bağlı olarak her bir homojen tüketici segmenti için içme sütü profillerinin dizayn edilmesi ve etkili pazarlama stratejilerinin harekete geçirilebilmesi amacıyla, bu çalışma planlanmıştır.

\section{Materyal ve Yöntem}

\subsection{Materyal}

Araştırmanın birincil verilerini, 2017 yılında Iğdır ilinde ikamet eden ve içme sütü tüketen hane halkları ile yüz yüze yapılan anketlerden elde edilen veriler oluşturmaktadır. İkincil veriler ise, çeşitli kurum ve kuruluşların (TUIK, FAOSTAT gibi) verileri ile yerli ve yabancı bilimsel çalışma, rapor, dergi ve çeşitli yayınlardan temin edilen araştırma sonuçlarından sağlanmıştır.

\subsection{Metotlar}

\subsection{1. Örnek büyüklüğ̈̈nün belirlenmesinde uygulanan metot}

Iğdır ilindeki hane halklarını temsil etme niteliği taşıyan ve örnek kitleye seçilenlerin tek yönlü kümelenmesini önlemek için ilin doğu-batı, kuzeygüney yönlerini kapsayan ana popülasyondaki hane halkları mekanik sıralama yöntemiyle tesadüfi olarak seçilmiş ve örneklem büyüklüğü belirlenmiştir. Araştırma bölgesinde daha önce bölge orijinli içme sütü tüketenlerin oranlarına yönelik bir veriye ulaşılamadığından, içme sütü tüketen ve tüketmeyen hane halklarının oranları belirlemek için bir ön saha çalışması yürütülmüş ve tesadüfi olarak seçilen tüketicilerin içme sütü tüketme oranı $\% 88.2$ ve tüketmeme oranı ise \%11.8 olarak hesaplanmıştır. Mevcut oranlar dikkate alınarak, ana kitle büyüklüğünün bilinmemesi durumunda teorik olarak belirlenen örnek kitle büyüklüğü, aşağıdaki denklem yardımıyla hesaplanmıştır (Topcu, 2015).

$$
n=\frac{Z^{2} * p^{*}(1-p)}{c^{2}}
$$

Burada;

n: Örnek büyüklüğü

$Z: Z$ değeri, (\%95 güven aralığında 1.96)

$\mathrm{p}$ : Tüketicilerin içme sütü tüketim oranları $(0.882)$

q: (1-p) İçme sütü tüketmeme oranı (0.118)

c: Hata terimi, $(0.05= \pm 5)$

Yukarıdaki eşitlikte bölge orijinli içme sütü tüketim olayının teorik görülme sıklığı ve gerçekleşmeme ihtimalleri dikkate alınarak, araştırma bölgesinde 
yapılması gereken anket sayısı 160 olarak hesaplanmıştır.

\subsubsection{Anket formlarının hazırlanmasinda uygulanan metot}

Iğdır ilinde içme sütü tüketen hane halklarının satın alma tutum ve davranışları belirleyen içsel ve dişsal ürün nitelikleri ile tüketicilerin sosyoekonomik ve demografik karakteristikleri ile ilgili faktörler, yerli ve yabancı araştırmalarda kullanılan değişkenlerin bölgelere ve ilgili ürüne uyarlanması ile elde edilmiştir. Ön araştırma ve hipotetik yaklaşımlarla tüketicilerin içme sütü satın alma kararı üzerinde etkili olan üretim ve işleme teknikleri, ürün içeriği, bölge orijini, marka ve fiyat gibi perakende seviyesinde dikkate alınan 6 ana pazarlama karması faktörleri ile onların 17 faktör seviyesi (organik ve geleneksel üretim teknikleri; UHT, pastörize ve ham süt işleme teknikleri; Doğu Karadeniz, Kuzeydoğu Anadolu, Marmara/Ege Bölgesi orijinleri; ulusal, özel ve jenerik marka tipleri; tam, yarım ve sıfır yağlı süt içerikleri; 3 TL/litre baz fiyatı yanında $\% 100$ ve \%200 fiyat artışları ile ödeme istekliliği duyarlıkları için hesaplanan 6 TL/litre ve 9 TL/litre) dikkate alınarak (Çizelge 1), Conjoint modelde orthogonal dizayn ile 20 içme sütü profili türetilmiştir (Çizelge 2).

Çizelge 1. Tüketicilerin içme sütü satın alma kararını etkileyen ürün nitelik ve nitelik seviyeleri

\begin{tabular}{lccc}
\hline Nitelikler & & Nitelik seviyeleri & \\
\hline \hline Üretim teknikler & Organik üretim & Geleneksel üretim \\
İşleme teknikleri & UHT süt & Pastörize süt & Ham (çĭ̆) süt \\
Marka & Ulusal marka & Özel marka & Jenerik marka \\
Üretim bölgesi (orijin) & Kuzeydoğu Anadolu & Doğu Karadeniz & Marmara/Ege \\
İçeriği (yağ oranı) & Tam yağlı süt & Yarım yağlı süt & Light süt \\
Fiyat & 3 TL & 6 TL & TL \\
\hline
\end{tabular}

Çizelge 2. Conjoint analizde orthogonal dizayn ile türetilen içme sütü profilleri

\begin{tabular}{|c|c|c|c|c|c|c|}
\hline Profil no & Üretim tekniği & İşleme tekniği & Orijini (bölgesi) & Marka & Ürün içeriği & Fiyat \\
\hline 1 & Organik & UHT süt & Doğu Karadeniz & Ulusal marka & Yarım yağlı süt & $6 \mathrm{TL}$ \\
\hline 2 & Organik & Ham süt & Marmara/Ege & Özel marka & Light süt & $6 \mathrm{TL}$ \\
\hline 3 & Geleneksel & UHT süt & Kuzeydoğu Anadolu & Özel marka & Yarım yağlı süt & $9 \mathrm{TL}$ \\
\hline 4 & Organik & Pastörize süt & Kuzeydoğu Anadolu & Jenerik marka & Yarım yağlı süt & $3 \mathrm{TL}$ \\
\hline 5 & Organik & UHT süt & Kuzeydoğu Anadolu & Jenerik marka & Tam yağlı süt & $6 \mathrm{TL}$ \\
\hline 6 & Organik & UHT süt & Marmara/Ege & Ulusal marka & Tam yağlı süt & $3 \mathrm{TL}$ \\
\hline 7 & Organik & Pastörize süt & Doğu Karadeniz & Özel marka & Tam yağlı süt & $3 \mathrm{TL}$ \\
\hline 8 & Geleneksel & Pastörize süt & Kuzeydoğu Anadolu & Ulusal marka & Light süt & $6 \mathrm{TL}$ \\
\hline 9 & Organik & UHT süt & Marmara/Ege & Jenerik marka & Light süt & $9 \mathrm{TL}$ \\
\hline 10 & Geleneksel & Ham süt & Marmara/ege & Jenerik marka & Yarım yağlı süt & $3 \mathrm{TL}$ \\
\hline 11 & Organik & Pastörize süt & Doğu Karadeniz & Jenerik marka & Light süt & $9 \mathrm{TL}$ \\
\hline 12 & Organik & Pastörize süt & Marmara/Ege & Özel marka & Yarım yağlı süt & $6 \mathrm{TL}$ \\
\hline 13 & Geleneksel & Ham süt & Doğu Karadeniz & Jenerik marka & Tam yağlı süt & $6 \mathrm{TL}$ \\
\hline 14 & Organik & Ham süt & Doğu Karadeniz & Ulusal marka & Yarım yağlı süt & $9 \mathrm{TL}$ \\
\hline 15 & Geleneksel & UHT süt & Doğu Karadeniz & Özel marka & Light süt & $3 \mathrm{TL}$ \\
\hline 16 & Organik & Ham süt & Kuzeydoğu Anadolu & Ulusal marka & Light süt & $3 \mathrm{TL}$ \\
\hline 17 & Geleneksel & Pastörize süt & Marmara/Ege & Ulusal marka & Tam yağlı süt & $9 \mathrm{TL}$ \\
\hline 18 & Organik & Ham süt & Kuzeydoğu Anadolu & Özel marka & Tam yağlı süt & $9 \mathrm{TL}$ \\
\hline $19^{\mathrm{a}}$ & Geleneksel & Ham süt & Kuzeydoğu Anadolu & Özel marka & Tam yağlı süt & $3 \mathrm{TL}$ \\
\hline $20^{\mathrm{a}}$ & Organik & Ham süt & Marmara/Ege & Ulusal marka & Light süt & $3 \mathrm{TL}$ \\
\hline
\end{tabular}

${ }^{a}$ Holdout

İçme sütüne ilişkin faktör ve faktör seviyeleri ile 20 ürün profili anket formlarına aktarılarak hedef tüketici kitlelerine sunulmuştur.
Diğer taraftan hedef tüketici piyasalarının bölümlendirilmesinde kullanılan içme sütü tüketim sıklıkları ( her gün, haftada 3-4 ve 15 günde 3-4 kez 
tüketim) dikkate alınmıştır. $\mathrm{Bu}$ tüketim sıklıklarına dayalı olarak içme sütü tüketen tüketiciler sırasıyla yoğun, 1lımlı ve düşük düzeyde içme sütü tüketenler olarak üç hedef piyasa segmenti oluşturulmuştur (Kotler ve Armstrong, 2004).

\subsubsection{Verilerin istatistiksel analizinde uygulanan metotlar}

Conjoint analiz, perakendecilerin farklılaştırılmış ürün modelleri teklifleri karşısında tüketicilerin satın alma kararlarına çok değişkenli istatistik tekniklerini uygulayarak etkili ürün tasarımlarını geliştirmek ve piyasa paylarını tespit etmek için kullanılan bir piyasa araştırma aracıdır. $\mathrm{Bu}$ teknik, faktör ve seviyeleri tarafından tanımlanan alternatif ürün profillerinin bireysel ve kitlesel değerlendirilmesinden elde edilen tüketici satın alma modellerinin yapıları hakkında araştırmacılara bilgi sağlar (Green ve Krieger, 1991). Conjoint analizi uygulamak için kullanılan veriler, alternatif ürün profillerinin tüketici değerlendirmelerini kapsamaktadır. Bu analiz tekniğinde, her bir faktör ve onların seviyelerinin ön piyasa araştırması ile belirlenmesi, fraksiyonel faktöriyel tasarımı ve ölçek tipinin belirlenmesini takip eden veri toplama süreci, dört aşamada gerçekleşir ve bu aşamaları takiben conjoint model tanımlamas1 yapılır (Topcu, 2019).

Conjoint analizin birinci ve ikinci adımda, uygun faktör ve faktör seviyeleri belirlenerek, tam profil yaklaşımı ile kart dizaynları gerçekleştirilmektedir. Mevcut çalışmadaki 6 faktör ve 17 faktör seviyesi belirlenmiştir ve takip eden aşamada, Conjoint analiz için tam profil yaklaşımı altında tüketiciler tercih sıralamas1 yapabilsin diye onlara sunulan farklı kombinasyonların hesaplanmasında kullanılan faktör seviyeleri dikkate alınarak, toplam 486 (5 x 2) adet kuramsal senaryo elde edilmiştir. Fakat, elde edilen ürün profil sayısının çok fazla olmasından dolayı tüketicilerin bunları anlamlı bir şekilde sıralaması olanaksızdır. Bu yüzden, Generate Orthogonal Design prosedürü kullanılarak, fraksiyonel faktöriyel tasarım ile içme sütü profil sayısı 20 adet profile indirgenmiştir (Çizelge 2).

Son olarak, her bir faktörün nispi önemi ve faktör seviyelerinin kısmi faydalarını belirlemek için faktörler ile derecelemeleri arasındaki beklenen ilişkileri belirleyen modelin faktör alt komutları vasitasiyla tanımlanmalıdır. Bunun için en yaygın kullanılan model, niteliklerin ayrı ayrı kısmi faydalarının toplamlarını ifade eden doğrusal modellerdir (SPSS Conjoint 20.0, 2015). Conjoint modellerde ayrik modeller; faktör seviyelerinin kategorik ve faktörler ile sıralamalar arasında her hangi bir ön görünün bulunulmadığını, fakat doğrusal modeller; faktörler ile sıraları arasındaki doğrusal ilişkileri pozitif ya da negatif yönlü olarak ifade ederler. Mevcut çalışmada; talep kanunundan dolayı fiyat negatif yönlü (linear less), marka, üretim ve işleme tekniği, ürün içeriği ve orijin (discrete) olarak modelde tanımlanmıştır.

\section{Bulgular ve Tartışma}

\subsection{Bölge orijinli içme sütü tüketen tüketicilerin demografik ve ekonomik özellikleri}

Bölge orijinli içme sütü tüketen tüketicilerin yoğun, ılımlı ve düşük düzeyde süt tüketim sıklıklarına göre segmente edilmiş homojen gruplar itibariyle bazı demografik ve ekonomik özellikler, Çizelge 3'de verilmiştir. Ankete katılanların \%49'u erkek ve \%51'i kadınlardan oluşmuştur. Yoğun ve düşük düzeyde içme sütü tüketen gruplarda kadınlar, fakat 1lımlı düzeyde tüketen gruplarda ise erkekler yoğunluk sergilemiştir. Diğer taraftan, tüketicilerin bölge orijinli içme sütü tüketimi ile ilgili tutum ve davranışlarının şekillenmesinde önemli rol oynayan faktörlerden bir diğeri medeni durumdur. Bireylerin gida tüketimi ve harcama yapısı evli ve bekâr oluşlarına göre farklılık arz etmektedir. $\mathrm{Bu}$ bağlamda ankete cevap verenlerin \%43'ü bekâr ve \%57'si evli bireylerden oluşmuştur. Evli bireyler bütün segmentlerde yoğunluk arz etmektedir.

Eğitim seviyesi ve mesleki statü, arasında güçlü bir ilişkinin bulunduğu ve yüksek eğitimli bireylerin daha yüksek gelire sahip olmalarının beklenmesinden dolayı tüketicilerin satın alma kararlarında önemli derecede rol oynamaktadır. Ankete katılan hane halklarının eğitim durumu, ailenin yaşam tarzı ve vizyonu hakkında önemli ipuçları sunmaktadır. Bu ilişkilere bağlı olarak ankete katılanların \%41'i yüksekokul mezunu ve \%34'ü memurlardan oluşmuştur. Aynı zamanda bütün gruplarda yüksekokul mezunları ile memur mesleki statü yoğunluk arz etmektedir (Çizelge 3). Bireylerin bölge orijinli içme sütü tüketimine yönelimleri yaş ve yaşam döngüsü ile değişip farklılaştığı için yaş, aile büyüklüğ̈̈ ve tüketim miktarları arasındaki ilișki, onların harcamaları hakkında da önemli bilgiler sunmaktadır. Bu sebeple ankete katılanların ortalama yaş1 38 ve aile büyüklüğü 4.11 birey olup; yoğun, 11 mlı ve düşük düzeyde içme sütü tüketen gruplarda ise ortalama yaş ve birey olarak aile büyüklükleri sırasıyla 40 ve $4.35,37$ ve $3.87,36$ ve 4.27 olarak hesaplanmıştır (Çizelge 3).

Diğer taraftan tüketicilerin ekonomik seviyeleri ürün tercihi ve satın alma kararlarında önemli bir rol oynamaktadır. Özellikle pazar bölümlendirme, hedef pazar belirleme ve konumlandirma ile ilgili stratejik kararların alınmasında tüketicilerin gelir ve harcama düzeylerine ilişkin ekonomik düzeyleri büyük öneme sahiptir. $\mathrm{Bu}$ bağlamda tüketicilerin ortalama aylık gelirleri 3555 TL ve harcamaları ise 3188 TL iken; yoğun, 11 ımlı ve düşük düzeyde içme sütü tüketen tüketici kitlelerinin ise sirasıyla $3716 \mathrm{TL}$ ve $3305 \mathrm{TL}$, $3491 \mathrm{TL}$ ve $3185 \mathrm{TL}, 3477 \mathrm{TL}$ ve 3041 TL'dir. Tüketicilerin toplam harcamaları ile süt harcamaları arasındaki doğrusal ilişkiye bağlı olarak süt tüketim miktarları da benzer bir trend sergilemiş̧ir. Toplam tüketici kitlesi için aylık ortalama hane halkı süt tüketim miktarı ve süt harcaması sırasıyla 17.4 litre ve $71.7 \mathrm{TL}$ 
olarak hesaplanmıştır. Benzer şekilde yoğun, 1lımlı ve düşük düzeyde içme sütü tüketen kitleler için sırasıyla
27 litre ve 75 TL, 13.7 litre ve 73.9 TL, 12.4 litre ve 63.6 TL olarak belirlenmiştir (Çizelge 3).

Çizelge 3. İçme sütü tüketim sıklıklarına göre tüketicilerin demografik ve ekonomik özellikleri

\begin{tabular}{|c|c|c|c|c|c|c|}
\hline \multirow{2}{*}{\multicolumn{3}{|c|}{ Demografik nitelikler }} & \multicolumn{3}{|c|}{ İçme sütü tüketim sıklığı kümeleri } & \multirow[b]{2}{*}{$\begin{array}{c}\text { Toplam tüketici } \\
\text { kitlesi }\end{array}$} \\
\hline & & & $\begin{array}{l}\text { Yoğun düzeyde } \\
\text { tüketenler }\end{array}$ & $\begin{array}{l}\text { Ilımlı düzeyde } \\
\text { tüketenler }\end{array}$ & $\begin{array}{l}\text { Düşük düzeyde } \\
\text { tüketenler }\end{array}$ & \\
\hline \multirow{2}{*}{ Cinsiyet } & \multirow{2}{*}{\multicolumn{2}{|c|}{$\begin{array}{l}\text { Erkek } \\
\text { Kadın }\end{array}$}} & 18 & 42 & 18 & 78 \\
\hline & & & 30 & 33 & 19 & 82 \\
\hline \multirow{3}{*}{$\begin{array}{l}\text { Medeni } \\
\text { durum }\end{array}$} & \multicolumn{2}{|l|}{ Bekâr } & 21 & 32 & 16 & 69 \\
\hline & \multicolumn{2}{|l|}{ Evli } & 27 & 43 & 21 & 91 \\
\hline & \multicolumn{2}{|l|}{ Okur-yazar } & 0 & 1 & 0 & 1 \\
\hline \multirow{3}{*}{ Eğitim } & \multirow{2}{*}{\multicolumn{2}{|c|}{$\begin{array}{l}\text { İlköğretim } \\
\text { Ortaöğretim }\end{array}$}} & 12 & 21 & 15 & 48 \\
\hline & & & 16 & 24 & 6 & 46 \\
\hline & \multicolumn{2}{|c|}{ Yükseköğretim } & 20 & 29 & 16 & 65 \\
\hline \multirow{6}{*}{ Meslek } & \multicolumn{2}{|c|}{ İş adamı } & 12 & 11 & 5 & 28 \\
\hline & \multirow{2}{*}{\multicolumn{2}{|c|}{$\begin{array}{l}\text { Memur } \\
\text { İsci }\end{array}$}} & 15 & 24 & 16 & 55 \\
\hline & & & 11 & 21 & 13 & 45 \\
\hline & \multicolumn{2}{|l|}{ Esnaf } & 3 & 9 & 0 & 12 \\
\hline & \multicolumn{2}{|l|}{ Emekli } & 2 & 7 & 2 & 11 \\
\hline & \multicolumn{2}{|l|}{ Ev hanımı } & 5 & 3 & 1 & 9 \\
\hline \multirow{3}{*}{\multicolumn{2}{|c|}{ Yaş $(y l l)$}} & $n$ & 48 & 75 & 37 & 160 \\
\hline & & $\bar{x}$ & 40.44 & 37.09 & 36.35 & 37.93 \\
\hline & & $S D$ & 10.23 & 10.55 & 10.28 & 10.46 \\
\hline \multirow{3}{*}{\multicolumn{2}{|c|}{ Aile büyüklüğü (kişi) }} & $n$ & 48 & 75 & 37 & 160 \\
\hline & & $\bar{x}$ & 4.35 & 3.87 & 4.27 & 4.11 \\
\hline & & $S D$ & 1.84 & 1.56 & 1.81 & 1.71 \\
\hline \multirow{3}{*}{\multicolumn{2}{|c|}{ 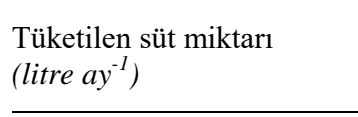 }} & $n$ & 48 & 75 & 37 & 160 \\
\hline & & $\bar{x}$ & 26.96 & 13.67 & 12.35 & 17.35 \\
\hline & & $S D$ & 30.35 & 14.34 & 11.56 & 20.94 \\
\hline \multirow{3}{*}{\multicolumn{2}{|c|}{ Toplam gelir $\left(T L a y^{-1}\right)$}} & $n$ & 48 & 75 & 37 & 160 \\
\hline & & $\bar{x}$ & 3716.3 & 3490.67 & 3476.76 & 3555.13 \\
\hline & & $S D$ & 2021.65 & 1967.52 & 1802.19 & 1938.14 \\
\hline \multirow{3}{*}{\multicolumn{2}{|c|}{ Toplam harcama $\left(T L a y^{-1}\right)$}} & $n$ & 48 & 75 & 37 & 160 \\
\hline & & $\bar{x}$ & 3305.00 & 3185.33 & 3041.35 & 3187.94 \\
\hline & & $S D$ & 1767.82 & 1870.23 & 1883.66 & 1730.40 \\
\hline \multirow{3}{*}{\multicolumn{2}{|c|}{$\begin{array}{l}\text { Toplam gida harcamas1 } \\
\left(\text { TL } a y^{-1}\right)\end{array}$}} & $n$ & 48 & 75 & 37 & 160 \\
\hline & & $\bar{x}$ & 1279.21 & 1091.15 & 1153.65 & 1162.02 \\
\hline & & $S D$ & .733 .02 & 654.97 & 677.04 & 684.69 \\
\hline \multirow{3}{*}{\multicolumn{2}{|c|}{$\begin{array}{l}\text { Toplam süt harcamas1 } \\
\left(T L a y^{-1}\right)\end{array}$}} & $n$ & 48 & 75 & 37 & 160 \\
\hline & & $\bar{x}$ & 74.66 & 73.92 & 63.59 & 71.74 \\
\hline & & $S D$ & 60.73 & 59.01 & 46.88 & 56.80 \\
\hline
\end{tabular}

\subsection{Tüketicilerin bölge orijinli içme sütü tüketim memnuniyetleri}

Türk tüketicilerin içme sütü tüketim sıklıklarına göre içme sütü satın alma kararında pazarlama karması bileşenlerinin nitelikleri, niteliklerin nispi önemleri ve nitelik seviyelerinin fayda düzeyleri, Çizelge 4'de sunulmuştur. Araştırma sonuçları; yoğun düzeyde içme sütü tüketen tüketicilerin memnuniyetleri üzerinde en etkili faktörlerin üretim tekniği, fiyat, süt içeriği ve bölge orijini olduğunu ve bunların nispi önemlerinin sirasiyla, \%31.20, \%18.75, \%17.40 ve \%14.65 olarak belirlendiğini ortaya koymuştur. Benzer şekilde 1 lımlı düzeyde içme sütü tüketenlerde ise üretim tekniği (\%31.25), fiyat (\%17.20), işleme tekniği (\%16.64) ve bölge orijini (\%14.14) tüketim memnuniyeti üzerinde en etkili faktörlerdir. Düşük düzeyde içme sütü tüketen segmentin memnuniyeti üzerinde marka (\%26.56), üretim tekniği (\%24.55), bölge orijini $(\% 16.99)$ ve işleme tekniği (\%14.22) önem arz eden faktörlerdir. Genel olarak ise toplam tüketicilerin içme sütü tüketim memnuniyetinde sirasiyla $\% 29.69, \% 15.82, \% 15.29$ ve $\% 14.95$ 'lik nispi önemlere sahip üretim tekniği, fiyat, marka ve bölge orijini büyük bir öneme sahiptir. Diğer taraftan, içme sütü tüketen tüketicilere en yüksek kısmi faydaları sağlayan faktör düzeyleri bütün tüketici segmentleri ve kitlesel tüketiciler için organik üretim, pastörize süt, ulusal marka, tam yağlı süt, Doğu Karadeniz orijini ve düşük fiyat seviyelerinden oluşmaktadır (Çizelge 4).

Tüketicilerin süt ve süt ürünleri tüketim memnuniyeti üzerinde organik üretim tekniği (Bellows ve ark., 2010; Tsourgiannis ve ark., 2011; Almli ve ark., 2015; Liang, 2015; Götze ve ark., 2016; Pinto ve ark., 
2016; Topcu, 2019; Topcu ve Sar1, 2019), ham ve pastörize süt işleme teknikleri (Aquailanti ve ark., 2013; Grubor ve Djokic, 2015; Murhy ve ark., 2015; Topcu, 2019; Topcu ve Sarı, 2019), düşük ve orta fiyat seviyeleri (Steenhuis ve ark., 2011; Adanacioğlu ve Albayram, 2012; Almli ve ark., 2015; Liang, 2015; Murhy ve ark., 2015; Götze ve ark., 2016; Topcu, 2019; Topcu ve Sarı, 2019), tam yağlı süt içeriği (Sichmann ve ark., 2011; Adanacıoğlu ve Albayram, 2012; Almli ve ark., 2015; Grubor ve Djokic, 2015; Murhy ve ark., 2015; Porral ve ark., 2015; Gracia, 2016; Pinto ve ark.,
2016; Topcu, 2019; Topcu ve Sar1, 2019), ulusal ve özel markalar (Enneking ve ark., 2007; Sichmann ve ark., 2011; Murhy ve ark., 2015; Pelsmaeker ve ark., 2017; Topcu, 2019; Topcu ve Sarı, 2019) ve korunan bölge orijinleri (Adanacioğlu ve Albayram, 2012; Cacciolatti ve ark., 2015; Aprile ve ark., 2016; Gracia, 2016; Grunert ve Aachmann, 2016; Topcu, 2019; Topcu ve Sarı, 2019) faktörlerinin daha etkili olduğuna işaret eden araştırma sonuçları, mevcut çalışmanın sonuçlarını da desteklemektedir.

Çizelge 4. Iğdır ilindeki tüketicilerin içme sütü satın alma kararı üzerinde etkili faktörlerin nispi önemi ve faktör seviyelerinin kısmı faydaları

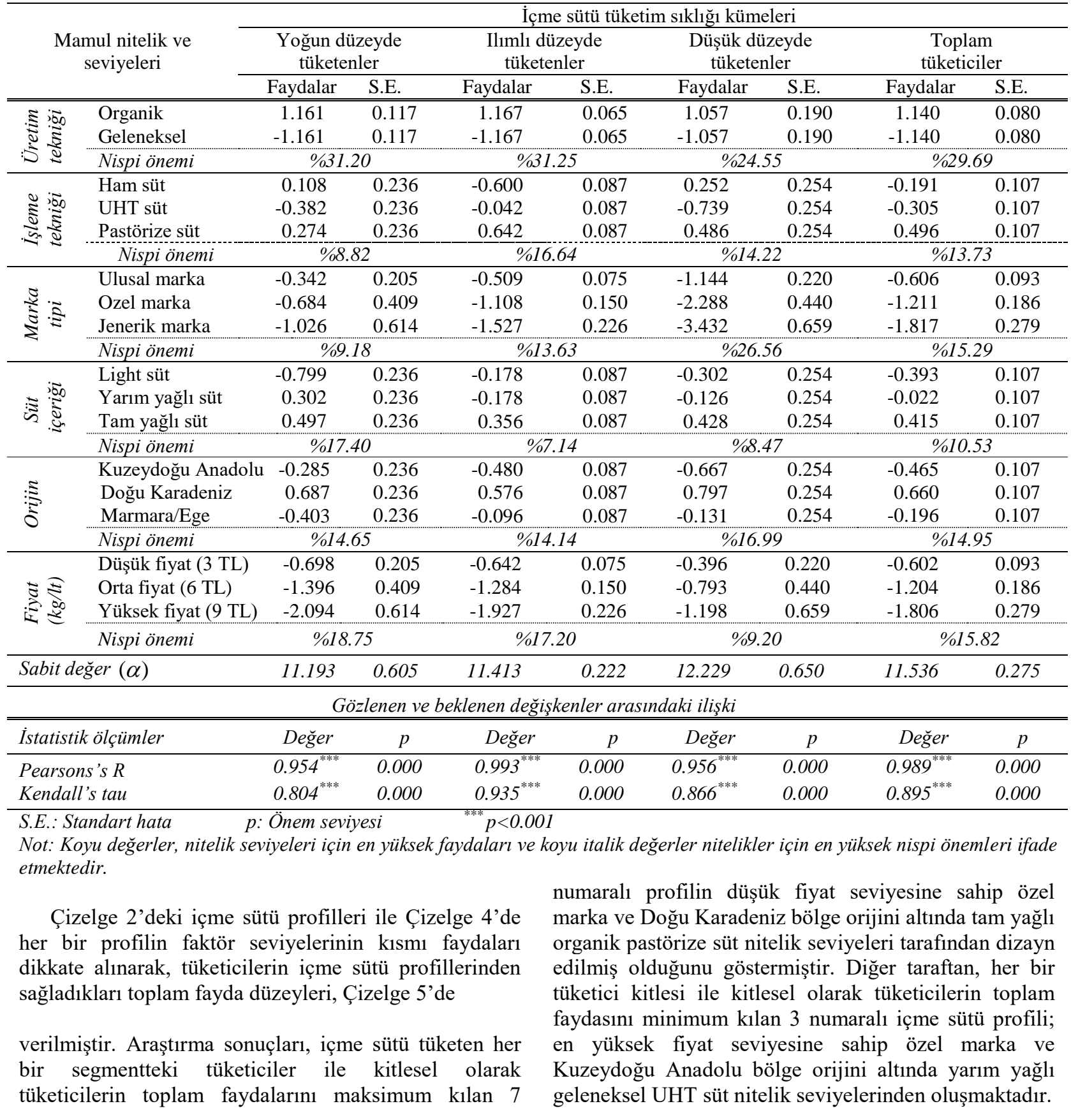


Çizelge 5. Iğdır ilindeki tüketicilerin her bir küme ve mamul profilleri için toplam fayda düzeyleri

\begin{tabular}{|c|c|c|c|c|c|c|c|c|}
\hline \multirow{3}{*}{ Profil numarası } & \multicolumn{6}{|c|}{ İçme sütü tüketim sıklığı kümeleri } & \multirow{2}{*}{\multicolumn{2}{|c|}{$\begin{array}{l}\text { Toplam } \\
\text { tüketiciler }\end{array}$}} \\
\hline & \multicolumn{2}{|c|}{$\begin{array}{c}\text { Yoğun düzeyde } \\
\text { tüketenler }\end{array}$} & \multicolumn{2}{|c|}{$\begin{array}{c}\text { Ilımlı düzeyde } \\
\text { tüketenler }\end{array}$} & \multicolumn{2}{|c|}{$\begin{array}{l}\text { Düşük düzeyde } \\
\text { tüketenler }\end{array}$} & & \\
\hline & Faydalar & Siralama & Faydalar & Siralama & Faydalar & Siralama & Faydalar & Siralama \\
\hline 1 & 11.713 & 2 & 10.585 & 3 & 12.272 & 2 & 11.313 & 3 \\
\hline 2 & 9.180 & 12 & 9.314 & 10 & 10.024 & 8 & 9.481 & 9 \\
\hline 3 & 6.889 & 20 & 6.511 & 20 & 6.154 & 20 & 6.587 & 20 \\
\hline 4 & 9.525 & 10 & 9.110 & 11 & 8.349 & 15 & 9.062 & 12 \\
\hline 5 & 9.762 & 9 & 9.603 & 9 & 8.083 & 17 & 9.300 & 11 \\
\hline 6 & 11.026 & 3 & 11.647 & 2 & 11.304 & 5 & 11.382 & 2 \\
\hline 7 & 12.430 & 1 & 12.404 & 1 & 12.313 & 1 & 12.434 & 1 \\
\hline 8 & 7.484 & 19 & 8.437 & 16 & 8.752 & 12 & 8.224 & 17 \\
\hline 9 & 7.650 & 18 & 8.810 & 14 & 7.484 & 18 & 8.159 & 18 \\
\hline 10 & 8.315 & 15 & 7.203 & 19 & 7.339 & 19 & 7.568 & 19 \\
\hline 11 & 9.396 & 11 & 10.166 & 7 & 9.637 & 10 & 9.816 & 8 \\
\hline 12 & 10.447 & 5 & 10.556 & 4 & 10.434 & 7 & 10.539 & 6 \\
\hline 13 & 8.902 & 14 & 7.767 & 18 & 8.424 & 14 & 8.259 & 16 \\
\hline 14 & 11.015 & 4 & 9.942 & 8 & 11.867 & 3 & 10.711 & 4 \\
\hline 15 & 8.156 & 16 & 8.852 & 12 & 8.244 & 16 & 8.545 & 14 \\
\hline 16 & 10.338 & 6 & 10.171 & 6 & 11.029 & 6 & 10.419 & 7 \\
\hline 17 & 7.964 & 17 & 8.712 & 15 & 9.613 & 11 & 8.699 & 13 \\
\hline 18 & 9.896 & 8 & 8.821 & 13 & 9.813 & 9 & 9.418 & 10 \\
\hline 19 & 8.970 & 13 & 7.772 & 17 & 8.501 & 13 & 8.342 & 15 \\
\hline 20 & 10.220 & 7 & 10.555 & 5 & 11.565 & 4 & 10.688 & 5 \\
\hline
\end{tabular}

Not: Koyu ve koyu italik değerler, maksimum ve minimum toplam fayda değerlerine işaret etmektedir.

\section{Sonuç ve öneriler}

Araştırma sonuçlarına göre her bir tüketici segmenti ile toplam tüketici kitlesi, Doğu Karadeniz Bölge orijini ile tescillenmiş özel marka adı altında düşük fiyatlı tam yağlı organik pastörize süt profilinden maksimum fayda sağlarken; Kuzeydoğu Anadolu Bölge orijini ile tescillenmiş özel marka adı altında yüksek fiyatlı yarım yağlı geleneksel üretim modelli UHT süt profili ile minimum fayda temin etmiştir.

Tüketicilerin toplam faydaların maksimum kılan Doğu Karadeniz ve Marmara Bölge orijinli organik tam ve yarı yağlı içme sütlerinin düşük ve orta fiyat seviyelerinde özel ve ulusal markalı pastörize ve UHT sütlerin gerçek ya da bileşik mamul imajları altında farklılaştırılarak, yoğun bir şekilde perakendeci düzeyinde konumlandırılmalıdır. Diğer taraftan tüketicilerin toplam faydalarını minimum kılan ve tüketimde daha az tatmin sağlayan Kuzeydoğu Anadolu Bölge orijinli geleneksel üretim modelleri ile üretilen yarım yağlı ve light içme sütlerinin orta ve yüksek fiyatlı pastörize ve UHT süt imajları altında perakende sunumlarına daha az yer verilmelidir. Dolayısıyla tüketici memnuniyeti üzerinde ayırt edici niteliklere sahip olan organik üretim teknikleri ile Doğu Karadeniz Bölgesi'nde üretilmiş tam yağlı ve düşük/orta fiyatlı pastörize içme sütü niteliklerine yönelik dizayn ve sunumlara ağırlık verilmelidir.

Sonuç olarak, tüketim memnuniyeti üzerinde pozitif etkiye sahip olan içme süt profillerinin yoğun fakat tüketici tatminini negatif etkileyen içme sütü profillerinin minimum düzeylerde pazarlama karması bileşenlerine göre dizayn edilmesi ve perakende düzeyinde konumlandırılması, hem hedef kitlellerin toplam faydalarını maksimum kılarak daha fazla içme sütü tüketimini gerçekleştirmelerine hem de arz zincirinde fonksiyon gösteren işletmelerin sürdürülebilir ve daha etkin bir şekilde faaliyet göstererek yıllık faaliyet kar marjlarını daha yüksek düzeylere çıkarmalarına olanak sağlanabilir.

\section{Teşekkür}

BAP-2015/409 kodlu araştırma projesinden türetilen mevcut çalışmayı, finansal olarak destekleyen Atatürk 
Üniversitesi Bilimsel Araştırma Projeleri Fonu'na teşekkür ederim.

\section{Kaynaklar}

Adanacioğlu, H., Albayram, Z., 2012. A conjoint analysis of consumer preferences fot traditional cheeses in Turkey: A case study on Tulum Cheese. Korean J. Food Sci. An., 32 (4): 458-466.

Akbay, C., Jones, E., 2005. Food consumption behavior of socioeconomic groups for private labels and national brands. Food Qual. \& Pref., 16: 621-631.

Allen, S., Goddard, E., 2012. Consumer preferences for milk and yogurt attributes: How health beliefs and attitudes affect choices. Agricultural \& Applied Economics Association's 2012 Annual Meeting, 138-145, August 12-14, Washington.

Almli, V.L., Ovrum, A., Hersleth, M., Almoy, T., Naes T., 2015. Investigating individual preferences in rating and ranking conjoint experiments: A case study on semi-hard cheese. Food Qual. \& Pref., 39: 28-39.

Aprile, M.C., Caputo, V., Nayga, R.M., 2016. Consumers' preferences and attitudes toward local food products. J. Food Prod. Marketing, 22 (1): 1942.

Aquilanti, L., Santarelli, S., Babini, V., Osimani, A., Clementi, F., 2013. Quality evaluation and discrimination of semi-hard and hard cheeses from the Marché region using chemo-metric tools. Inter. Dairy J., 29: 42-52.

ASUD, 2019. Süt ve süt ürünleri tüketimi. Erişim adresi: http://www.asuder.org.tr (Erişim tarihi: 15 Mayıs 2019).

Azadbakht, L., Mirmiran, P., Esmaillzadeh, A., Azizi, F., 2005. Fairy consumption is inversely associated with the prevalence of the metabolic syndrome in Tehranian adults. Am. J. Clin. Nutr., 82 (3): 523-30.

Barnes, R.N., Bosworth, R.C., Bailey, D., Curtis, K.R., 2014. Connecting sensory quality characteristics and local designations to willingness to pay for cheese at the retail level. Int. Food \& Agribus. Manag. Rev., 17 (3): 115-138.

Bellows, A.C., Alcavaz, G., Hallman, W.K., 2010. Gender and food, a study of attitudes in the USA towards organic, local, U.S. grown and GM-free foods. Appetite 55: 540-550.

Black, R.E., Williams, S.M., Jones, I.E., Goulding, A., 2002. Children who avoid drinking cow milk have low dietary calcium intakes and poor bone health. Am. J. Clin. Nutr., 76: 675-80.

Braghieri, A., Girolami, A., Riviezzi, A.M., Piazzolla, N., Napolitano, F., 2014. Liking of traditional cheese and consumer willingness to pay. Ital. J. Anim. Sci., 13 (1): 155-162.

Cacciolatti, L.A., Garcia, C.C., Kalantzakis, M., 2015. Traditional food products: the effect of consumers' characteristics, product knowledge, and perceived value on actual purchase. J. Inter. Food and Agribus. Marketing, 27: 155-176.

Chamorro, A., Rubio, S., Miranda, F.J., 2015. The region-of-origin (ROO) effect on purchasing preferences: The case of a multiregional designation of origin. British Food J., 117 (2): 820-839.

Chen, M., 2007. Consumer attitudes and purchase intentions in relation to organic foods in Taiwan. Moderating effects of food-related personality traits. Food Qual. \& Pref., 6 (2): 1008-1015.

Cheng, L., Yin, C., Chien, H., 2014. Demand for milk quantity and safety in urban China: evidence from Beijing and Harbin. Aust. J. Agr. Resour. Ec., 59: 275-287.

Enneking, U., Neumann, C., Henneberg, S., 2007. How important intrinsic and extrinsic product attributes affect purchase decision. Food Qual. \& Pref., 18: 133-138.

FAOSTAT, 2019. Download and visualize data of livestock processed and primary product production. Access address: http://www.fao.org/faostat (Access data: 15 May1s 2019).

Furnols, M.F., Realini, C., Montossi, F., Sanudo, C., Campo, M.M., Oliver, M.A., Nute, G.R., Guerrero, L., 2011. Consumers' purchasing intention for lamb meat affected by country of origin, feeding system and meat price: A conjoint study in Spanish, France and United Kingdom. Food Qual. \& Pref., 22: 443451.

Götze, F., Mann, S., Ferjani, A., Kohler, A., Heckelei, T., 2016. Explaining market shares of organic food: evidence from Swiss household data. British Food J., 118 (4): 931-945.

Gracia, T.M.A., 2016. Consumers' willingness to pay for light, organic and PDO cheese. British Food J., 118 (3): 560-571.

Green, P.E., Krieger, A.M., 1991. Segmenting markets with conjoint analysis. Journal of Marketing, 55 (4): 20-31

Grubor, A., Djokic, N., 2016. Organic food consumer profile in the Republic of Serbia. British Food J., 118 (1): 164-182.

Grunert, K.G., Aachmann, K., 2016. Consumer reactions to the use of EU quality labels on food products: A review of the literature. Food Control, 59 (1): 178-187.

Gündüz, O., Kılıç, O., Emir, M., Aydın, G., 2013. Süt ve süt ürünleri tüketiminde tüketici tercihlerini etkileyen faktörler: Samsun ili örneği. GTED, 8 (1): 36-43.

Hair, J.F.J., Black, W.C., Babın, B.J., Anderson, R.E., 2010. Multivariate data analysis, (7th Edition) Prentice Hall, Upper Saddle River, NJ. ISBN-13: 978-0138132637.

Hill, H., Lynchehaun, F., 2002. Organic milk: attitudes and consumption patterns. British Food J., 104 (7): 526-542. 
Hollywood, L., Wells, L., Armstrong, G., Farley, H., 2013. Thinking outside the carton: attitudes towards milk packaging. British Food J., 115 (6): 899-912.

Kan, M., Gülçubuk, B., Küçükçongar, M., 2012. Coğrafi işaretlerin kırsal turizmde kullanılma olanakları. KMÜ Sosyal ve Ekon. Arş. Derg., 6(2): 52-64.

Karakaya, E., Akbay, C., 2014. İstanbul ili kentsel alanda tüketicilerin açık ve paket süt tüketim alışkanlıkları. Tarım Ekon. Derg., 20 (1): 17-27.

Konar, N., Kaya, I.H., Dalabasmaz, S., Poyrazoglu, E.S., Artik, N., 2014. Street milk and urban consumers in Turkey: A descriptive study. J. Verbrauch Leben S.M., 9: 23-29.

Kotler, P., Armstrong, G., 2004. Principles of marketing, 9th Edition, Prentice Hall, New Jersey.

Li, E.X., Drake, M.A., 2015. Sensory perception, nutritional role and challenges of flavored milk for children and adults. J. Food Sci., 80 (4): 665-670.

Liang, R., 2015. Predicting intentions to purchase organic food: the moderating effects of organic food prices. British Food J., 118 (1): 183-199.

Lim, K., Hu, W., Maynard, L.J., Goddard, E., 2014. A taste for safer beef? How much does consumers' perceived risk influence willingness to pay for country-of-origin labeled beef. Agribusiness, 30 (1): 17-30.

Liu, Z., Christopher, A., Kanter, C.A., Kent, D., Messer, K.D., Harry, M., Kaiser, H.M., 2013. Identifying significant characteristics of organic milk consumers: a CART analysis of an art factual field experiment. Appl. Econ., 45: 3110-3121.

Marcoz, E.M., Melewar, T.C., Dennis, C., 2014. The value of region of origin, producer and protected designation of origin label for visitors and locals: The case of fontina cheese in Italy. Int. J. Tour. Res., 18 (3): 236-253.

Markham, L., Auld, G., Bunning, M., Thilmany, D., 2014. Attitudes and beliefs of raw milk consumers in Northern Colorado. J. Hunger \& Env. Nut., 9 (4): 546-564.

Marshall, P., Eric, T.B., 2002. A unified approach to conjoint analysis models. J. Amer. Stat. Ass., 97 (459): 674-682.

Miles, S., Frewer, L.J., 2001. Investigating specific concerns about different food hazards. Food Qual. \& Pref., 12: 47-61.

Miller, G.D., Jarvis, K.J., McBean, L.D., 2000. Handbook of dairy foods and nut $\neg$ rition. In: Jensen RG, Kroger M, editors. The importance of milk and milk products in the diet. CRC Press, New York, pp. 4-24.

Miller, G.D., 2000. Benefits of dairy product consumption on blood pres $\neg$ sure in humans: A summary of the biomedical literature. J. Amer. Coll. Nut., 19 (2): 147-164.

Mobley, A.R., Jakob, D.J., Maulding, M., 2014. Attitudes, beliefs, and barriers related to milk consumption in older, low-income women. J. Nut. Educ. Behave., 46 (6): 554-559.

Munoz, R.R., Moya, M.M., Gil, J.M., 2015. Market values for olive oil attributes in Chile: a hedonic price function. British Food J., 117 (1): 358-370.

Murphy, M., Cowan, C., Meehan, H., 2015. A conjoint analysis of Irish consumer preferences for farmhouse cheese. British Food J., 106 (4): 288-300.

Murphy, M.M., Douglass, J.S., Johnson, R.K., Spence, L.A., 2008. Drinking flavored or plain milk is positively associated with nutrient intake and is not associated with adverse effects on weight status in US children and adolescents. J. Amer. Diet. Ass., 108: 631-639.

Pelsmaeker, S., Schouteten, J., Lagast, S., Dewettinck, K., Gellynck, X., 2017. Is taste the key driver for consumer preference? A conjoint analysis study. Food Qual. \& Pref. 62: 323-331.

Pinto, V.R.A., Melo, L.F., Balbino, D.F., Novaes, J.F., Negrete, M.C., Sousa, T.D., 2016. The evaluation of consumer behavior influence on the buying process of dairy products in Minas Gervais State, Brazil. J. Food and Nut. Res., 4(1): 51-59.

Porral, C.C., Jean-Pierre Levy-Mangin, J.P., 2015. Food private label brands: the role of consumer trust on loyalty and purchase intention. British Food J., 118 (3): 679-696.

Schleenbecker, R., Hamm, U., 2013. Consumers' perception of organic product characteristics. A review. Appetite, 71: 420-429.

Sichtmann, C., Wilken, R., Diamantopoulos, A., 2011. Estimating willingness-to-pay with conjoint analysis: Can consumer characteristics explain variations in accuracy? British J. Manage., 22: 628645.

SPSS Conjoint 20.0, 2015. SPSS Base 20 User's Guide 11, p. 161. Chicago, IL.

Steenhuis, I.H.M., Waterlander, W.E., Mul, A., 2011. Consumer food choices: the role of price and pricing strategies. Public Health Nutr., 14 (12): 2220-2226.

Şeker, İ., Şeker, P., Şahin, M., Özen, V.S., Akdeniz, A., Erkmen, O., Kışlalığlu, İ., Sargın, G., Doğu, G.B., 2012. Elazığ İli merkez ilçede tüketicilerin süt tüketim alışkanlıkları ve bu alışkanlıkları etkileyen faktörlerin belirlenmesi. Sağlık Bil. Vet. Derg., 26 (3): 131-143.

Topcu, Y., 2019. Tüketicilerin bölge orijinli organik içme sütü tercih profilleri ve piyasa payları: TRA1 Bölgesi örneği. MAS International Conference, 849859, May 2-5, 2019, Erzurum.

Topcu, Y., Sarı, M.M., 2019. Bölge orijinli konvansiyonel içme sütü tüketim memnuniyeti ve ödeme istekliliği: TRA1 Bölgesi örneği. ICAFOP 3. International Conference, 1298-1310, April 16-18, 2019, Trabzon.

Topcu, Y., 2015. Turkish consumer decisions affecting ice cream consumption. Ital. J. Food Sci., 27 (1): 2939. 
Topcu, Y., Uzundumlu, A.S., Baran, D., 2015. How sensory and hedonic quality attributes affect fresh red meat consumption decision of Turkish consumers? Ital. J. Food Sci., 27 (2): 181-189.

Tsourgiannis, T., Karasavvoglou, A., Florou, G., 2011. Consumers' attitudes towards GM free products in European Region. The case of the prefecture of Drama-Kavala-Xanthi in Greece. Appetite 57: 448458.

Uzunöz, M., Akçay, Y., 2012. A case study of probity model analysis of factors affecting consumption of packed and unpacked milk in Turkey. Econ. Res. Int., 2 (4): 1-8.
Vaskozen, T., 2003. Dietary minerals and modification of cardiovascular risk factors. J. Nut. Biochemistry, 14: 492-506.

Walke, M., Mtimet, N., Baker, D., Lindahl, J., Hartmann, M., Grace, D., 2014. Kenyan perceptions of aflatoxin: An analysis of raw milk consumption. The EAAE 2014 Congress: Agri-Food and Rural Innovations for Healthier Societies, 265-273, August 26-29, Ljubljana, Slovenia.

WDS, 2017. World Dairy Summit: per capita drinking milk consumption and population. Access address: http://www.idfwds2017.com (Access data: September 15, 2017). 